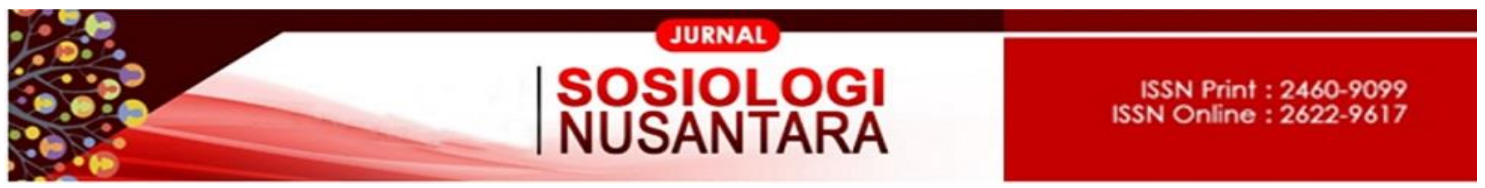

https://ejournal.unib.ac.id/index.php/jsn

DOI ://doi.org/10.33369/jsn.5.1.43-64

\title{
PEREBUTAN PENGARUH ANTARA NEGARA, PASAR, DAN MASYARAKAT SIPIL DALAM KASUS PELARANGAN KONVOI AREMANIA
}

\section{THE DISPUTE AMONG STATE, MARKET AND CIVIL SOCIETY IN CASE OF RESTRICTION OF AREMANIA'S CONVOY}

\author{
Indhar Wahyu Wira Harjo
}

indhar.wahyu@ub.ac.id

Fakultas Ilmu Sosial dan Ilmu Politik, UniversitasBrawijaya

\begin{abstract}
Abstrak
Relasi antara negara, korporasi, dan civil society tidak selalu bersifat saling medominasi,ketiganya berupaya untuk mencari kedudukan yang mendekati seimbang. Keseimbangan hubungan semacam itu dapat diamati pada peristiwa pelarangan konvoi Aremania (kelompok pendukung klub sepak bola Arema Malang). Pawai kendaraan bermotor Aremania sebelum dan setelah pertandingan Arema acapkali menjadi masalah bagi arus lalu lintas di Malang Raya. Pelanggaran aturan lalu lintas, kemacetan jalan hingga perusakan kendaraan lain merupakan persoalan yang sering terjadi saat arakarakan kendaraan Aremania dari dan menuju stadion. Kondisi tersebut menjadi dasar bagi Polisi Resort Kota Malang untuk melarang konvoi di hari ulang tahun Arema pada 11 Agustus 2016. Tulisan ini bermaksud mengurai praktik saling mempengaruhi yang melibatkan polisi, Manajemen Arema Cronus dan Aremania. Konsep tiga dimensi kekuasaan dari Steve Lukes digunakan sebagai koridor ulasan, lebih lanjut metode penelitian kualitatif dengan pendekatan analisis framing model Gamson dan Mondigliani diimplementasikan dalam penelitian ini. Hasil penelitian menunjukkan pertama terdapat perbedaan tujuan antarpihak mengenai konvoi perayaan ulang tahun Arema. Polisi berkepentingan mengatur Aremania agar tidak menyelenggarakan konvoi dengan argumen ketertiban umum dan regulasi lalu lintas. Di sisi lain, pengurus Arema bermaksud merayakan ulang tahun Arema secara besar-besaran bersama Aremania. Sedangkan Aremania berkeinginan melakukan konvoi untuk mempertahankan tradisi dan memeriahkan hari jadi Arema. Kedua, tujuan para pihak tersebut tidak ada satupun yang terwujud di hari itu. Perdebatan tersebut akhirnya melahirkan praktik yang berbeda dari tuntutan para pihak. Perayaan ulang tahun Arema pada tanggal 11 Agustus 2016 dilakukan dengan lomba-lomba, tasyakuran, bedah buku dan konser musik. Kegiatan ini tetap saja memunculkan mobilitas besar-besaran Aremania menuju tempat penyelenggaraan acara. Konvoi akhirnya juga diperbolehkan, namun dilakukan pada hari Minggu 14 Agustus 2016 dalam acara 'napak tilas' dengan rute sekitar $23 \mathrm{~km}$. Simpulan dari kondisi tersebut menunjukkan kegagalan negara untuk mengatur perilaku warga. Di sisi lain, hal ini mengilustrasikan pula keredupan kekuatan civil society, sebab civil society harus bekerja sama dengan korporasi untuk mengubah regulasi negara.
\end{abstract}


Perebutan pengaruh antara negara, pasar, dan masyarakat sipil dalam kasus

Kata Kunci:Arema, Aremania, kebijakan, konvoi dan sepak bola

\begin{abstract}
The relation among the state, corporates, and civil society is no longer dominating over one another, but more to seek a close-to-equal position instead. Such equal relation can be observed from the ban of Aremania (a group of faithful supporters of Arema Malang football club) convoy. The motorbike convoy prior to and after the Arema match has often caused a traffic problem in Malang. The violations of traffic rules, traffic congestion, and destruction of other vehicles during the parade from and to the stadium have been a frequently serious problem. The condition has been a primary concern Resort Police of Malang to prohibit the convoy to celebrate the birthday of Arema in August 11, 2016. The present study aims at investigating the practice of affecting each other involving police, the management of Arema, and Aremania. The study carries out the three-dimensional power from Steve Lukes as the discussion framework and Gamson and Mondigliani's framing analysis model as the method of qualitative research. The result of the study revealed that there were different objectives among the parties towards the issue of celebrating Arema's birthday. The police argued that they were in charge of banning the convoy with regards to public order and traffic regulations. On the other hand, the Arema management attempted to hold a big festivity along with Aremania. Meanwhile, Aremania insisted on having convoy to conserve the tradition and to enliven the annual commemoration. However, there was none of the aforementioned objectives was accomplished that day. The tension of arguments among all parties finally resulted to different practices.The birthday in August 11 was celebrated by presenting some contests, tasyakuran, book review, and music concert. However, these activities remained a trouble since they created a massive mobility of Aremania heading to the venues. At the end, the convoy was allowed to happen, but not exactly done at the D-day but rather in Sunday, August 14, 2016 in a program called 'napak tilas' with a 23-km route taken for the trip. This event points out the state's failure to organize the citizens' attitude. On the other hand, it also illustrates the faded power of civil society that is supposed to work with corporates to change state regulations.
\end{abstract}

Keywords:Arema, Aremania, policy, football convoi

\title{
PENDAHULUAN
}

Relasi timpang antara negara, korporasi dan masyarakat sipil merupakan permasalahan yang mendesak untuk dikaji dalam negara demokrasi. Setiap pilar kekuasaan tidak boleh memiliki kekuasaan mutlak dan kebebasan tanpa batas. Sebab, bila ada suatu pilar kekuasaan yang memiliki kekuasaan mutlak dan kebebasan tanpa batas, maka ia akan menutup pilar yang lain untuk mencapai nilai optimum dari suatu pencapaian. Selain itu, tata pemerintahan yang baik (good governance) yang dicitacitakan oleh pemerintah reformasi apabila terjadi hubungan dialektis tiga pilar negara, pasar, dan masyarakat sipil (Damsar 2010:147; Nugroho 2009:66-67). Tulisan ini 
berupaya mengurai silang sengkarut negara, korporasi, dan masyarakat sipil, terutama yang tampak dalam perayaan ulang tahun klub sepak bola Arema di Kota Malang, Jawa Timur.

Pemilihan peristiwa ini dilakukan dengan mempertimbangkan posisi penting sepak bola dalam kehidupan negara demokrasi. Sepakbola memberikan kontribusi yang besar untuk peningkatan kesadaran manusia terhadap dunia (Giulianotti and Robertson 2004:558). Sepakbola kerap pula membangkitkan penghayatan yang lebih dalam ketimbang agama, dan sebagai bagian dari jalinan masyarakat, sepakbola juga menjadi wahana pelestarian tradisi (Foer 2006:x). Selain itu, sepak bola juga dipandang sebagai institusi budaya besar yang membentuk dan merekatkan identitas nasional di seluruh dunia (Giulianotti 2006:29). Sehingga pemahaman terhadap relasi negara, korporasi dan masyarakat sipil dalam tulisan ini perlu dilakukan dalam dunia persepakbolaan untuk penafsiran yang lebih baik terhadap praktik demokrasi di Indonesia.

Penelitian ini bermula dari permasalahan tentang kegagalan negara dalam mengatur perilaku warga negaranya. Polisi sebagai instrumen penting dari negara bermaksud melarang konvoi kendaraan bermotor yang dilakukan Aremania (supporter klub sepak bola Arema) pada saat perayaan hari ulang tahun klub sepak bola Arema di wilayah Malang Raya. Akan tetapi, aturan yang diberlakukan Polisi Resort Kota Malang, Kota Batu dan Kabupaten Malang itu tidak berjalan lancar. Alih-alih menjadi pedoman dalam merayakan hari jadi Arema pada tanggal 11 Agustus 2016, keputusan itu justru ditentang Aremania yang bergandengan dengan Manajemen Arema. Aremania bersama Manajemen Arema melakukan penolakan dan tetap melakukan arak-arakan kendaraan bermotor pada saat berpesta merayakan ulang tahun tersebut.

Relasi antara negara, korporasi dan civil society menampilkan pola-pola yang tidak ajeg. Salah satu diantara ketiga entitas tersebut dapat menjadi pihak yang dominan satu sama lain. Dominasi salah satu pihak kepada pihak lain bukan menjadi kondisi ideal dalam negara demokrasi. Relasi yang menunjukkan keunggulan salah satu pihak semacam itu dinilai tidak merepresentasikan prinsip egalitarian yang menjadi asas penting dalam negara demokrasi. Sepanjang sejarah perkembangan politik di Tanah Air sejak masa pemerintahan Orde Lama, Orde Baru hingga Reformasi posisi warga cenderung merupakan subordinat dari negara dan di era globalisasi saat ini pasar menjadi kekuatan dominan di atas warga dan negara(Nugroho 2009:66). 
Fokus penelitian ini berada pada pembingkaian diskursus yang dilakukan atas kebijakan pelarangan konvoi dan penolakannya. Pembingkaian diskursus pelarangan konvoi tersebut mewarnai sejumlah media massa lokal yang beredar di Malang Raya, Radar Malang dan Surya Malang yang secara intensif memuat berita perihal kebijakan tersebut. Keputusan pelarangan konvoi itu telah dipublikasikan di media massa tersebut sejak tanggal 09 Agustus 2016, tepat dua hari sebelum ulang tahun klub berlogo kepala singa. Berita pelarangan konvoi tersebut faktanya menuai penolakan dari Aremania yang salah satunya disalurkan melalui jejaring sosial. Tulisan ini bermaksud untuk menunjukkan bahwa suporter, manajemen klub sepakbola dan negara sama-sama memiliki potensi untuk saling mempengaruhi.

\section{KAJIAN PUSTAKA}

Kaitan antara negara, pasar dan masyarakat sipil dalam dunia sepak bola bukan menjadi hal yang baru dalam kajian ilmu sosial. Kontrol yang dilakukan negara terhadap persepakbolaan telah terjadi di Indonesia sejak pendudukan pemerintah Belanda, seperti yang ditunjukkan dalam penelitian Freek Colombijn. NetherlandIndische Voetbal Bond (NIVB) yang merupakan asosiasi sepakbola bentukan warga Belanda mendapatkan prioritas ketimbang Persatuan Sepakbola Seluruh Indonesia (PSSI), sampai-sampai PSSI tidak diperbolehkan menggunakan lapangan sepakbola dan bertanding di sawah yang dialihfungsikan sebagai arena pertandingan sepakbola (Colombijn 2000:182). Kontrol negara semacam itu masih dapat diamati dalam kaitannya dengan upaya untuk mengatur kelompok suporter. Dalam temuan riset Andry Wibowo (2017) terlihat polisi melarang suporter sepakbola hadir di pertandingan yang rawan kerusuhan untuk menghindari bentrok antarsuporter. Meskipun pada akhirnya tanpa kehadiran suporter dari kubu lawan, kerusuhan kerap tetap terjadi. Di negara lain juga tampak sikap yang sama dari aparat terhadap perilaku penggemar sepak bola. Inggris misalnya, sejak 1989 pemerintah telah mengawasi stadion, perkelahian dan nyanyian-nyanyian yang terdapat di dalamnya (Foer 2006:91).

Selain menjadi sasaran kontrol oleh negara, sepakbola ternyata dapat pula menjadi anasir pembentuk nasionalisme negara. Kondisi semacam ini dapat diamati di negara Spanyol sejak abad ke-20, pada saat sepakbola dikaitkan dengan komponenkomponen yang membangun nasionalisme (Llopis Goig 2008:61). Sepak bola pun telah 
menjadi ranah yang strategis bagi korporasi untuk meraih keuntungan bisnis. Keadaan semacam ini dapat terlihat dari kehadiran penonton di stadion pada pertandingan sepak bola Amerika Serikat sejak tahun 1991 (Welki and Zlatoper 1994:494).

Riset-riset tersebut di atas menunjukkan relasi yang bersifat deterministik antara negara, pasar dan masyarakat sipil dalam dunia sepak bola. Tulisan singkat ini berupaya untuk mengambil posisi yang berbeda dengan kajian-kajian itu. Uraian di sini akan didasari oleh gagasan bahwa negara, korporasi dan masyarakat sipil berpotensi untuk mempengaruhi satu sama lain. Polisi dipandang sebagai representasi dari negara, Manajemen Arema diposisikan sebagai korporasi, dan Aremania dilihat sebagai civil society. Kerangka konsep yang digunakan untuk mengulas data yang diperoleh adalah cara pandang tiga dimensi kekuasaan yang digagas Steven Lukes. Cara pandang ini melihat praktik kuasa tidak sekedar berujung pada decision making, namun juga berhubungan dengan nondecisions making dan control over political agenda(Lukes 2005:25).

\section{METODE PENELITIAN}

Penelitian ini menggunakan paradigma konstruktivis dalam mengamati realitas sosial yang berupa pelarangan konvoi pada perayaan ulang tahun Arema. Paradigma konstruktivis berpandangan bahwa yang dipahami sebagai pengetahuan dan kebenaran objektif, sesungguhnya hasil konstruksi paradigma dan persepektif yang kita gunakan (Lubis 2018:66). Dengan demikian pengetahuan dan kebenaran yang diperoleh dari penelitian ini bukankah kebenaran yang bersifat absolut, namun kebenaran yang dikonstruksi berdasarkan teori dan sudut pandang yang spesifik.

Penelitian ini menggunakan metode penelitian kualitatif dengan pendekatan analisis framing model William Gamson dan Mondigliani. Pendekatan ini telah digunakan sejumlah ilmuwan sosial untuk meneliti berbagai masalah sosial yang terjadi di Indonesia. Beberapa penelitian yang mengimplementasikan pendekatan itu diantaranya adalah riset yang dilakukan Dina Fadiyah (2014) saat meneliti framing pemberitaan Ahok vs Lulung dalam konflik penertiban Pedagang Kaki Lima di Pasar Tanah Abang Jakarta usat dalam Media Online Detik.com. Penelitian Nanang Mizwar Hasyim (2016) dengan judul Konstruksi Citra Maskulinitas Calon Presiden juga mengimplementasikan analisis framing model Gamson dan Mondigliani untuk menelaah aspek maskulin yang ditonjolkan para calon presiden pada pemilihan umum 
tahun 2014. Selain itu, Syarifuddin (2016) dalam penelitiannya yang berjudul Representasi Ideologi Media di Balik Wacana Calon Gubernur memperlihatkan bahwa pendekatan analisis framing dapat membantu peneliti untuk menelaah konstruksi media massa terhadap calon gubernur yang dilakukan Tribunnews.com. Ketiga penelitian tersebut merepresenasikan kekuatan dari pendekatan analisis framing untuk menelaah pembentukan wacana yang dilakukan media massa. Kekuatan itulah yang dimanfaatkan dalam penelitian ini, sehingga relasi kuasa yang melibatkan negara, pasar dan civil society dapat diuraikan dengan baik.

Gagasan mereka terutama menghubungkan wacana media di satu sisi dengan pendapat umum di sisi yang lain (Eriyanto 2002:217). Ide ini didasari pemikiran bahwa public discourse is carried on in many different forums. Rather than a single public discourse, it is more usefull to think of a set of discourses that interact in complex ways(Gamson and Modigliani 1989:2) Cara pandang inilah yang dijadikan sebagai pijakan dalam pengumpulan dan analisis data di dalam penelitian ini, menghubungkan wacana pelarangan konvoi ulang tahun Arema yang berkembang di media massa dan masyarakat.

Sumber data dalam penelitian ini diperoleh dari media masa dan media sosial yang memuat pembicaraan tentang perayaan ulang tahun Arema yang ke-29. Media massa yang dipilih sebagai representasi penyebaran wacana yaitu Radar Malang dan Surya Malang, selanjutnya Twitter dipandang menjadi representasi wacana yang menyebar di masyarakat Kota Malang. Analisis dilakukan terhadap berita yang dimuat di dalam media massa tersebut menjelang hari perayaan ulang tahun klub sepak bola Arema. Lebih lanjut, fokus penelitian diarahkan pada pembingkaian wacana yang dibentuk di media massa mengenai kepentingan polisi, Manajemen Arema dan Aremania dalam perayaan hari ulang tahun Arema serta penolakan Aremania dikumpulkan dari jejaring sosial Twitter.

Data tersebut selanjutnya ditelaah menggunakan analisis framing dalam kerangka kerja Gamson dan Mondigliani. Analisis ini menelaah cara bertutur sebuah media dengan mengamati dua aspek penting. Dua aspek utama yang dijadikan sebagai instrumen untuk menganalisis berita adalah framing device dan reasoning device. Framing device berkaitan dengan perangkat utama yang digunakan untuk membingkai teks berita yang dapat berbentuk perumpamaan atau pengandaian, frasa, contoh, 
penggambaran dan gambar yang mendukung citra secara keseluruhan. Sedangkan reasoning deviceberhubungan dengan pemakaian kata, kalimat atau metafora yang menunjuk kepada ide tertentu, bentuknya dapat berupa analisis sebab-akibat, premis dasar, klaim moral dan efek dari bingkai yang dilakukan terhadap sebuah peristiwa (Eriyanto 2002:225-27).

Teknik pengumpulan data dilakukan dengan metode dokumentasi di media massa dan jejaring sosial Twitter. Dokumen dari sumber-sumber tersebut dinilai kelayakannya menggunakan kritik yang bersifat internal dan eksternal. Kritik internal terhadap dokumen dalam hal ini dimaksudkan pada strategi memeriksa substansi data berdasarkan aspek faktualnya, pertanyaan utama yang digunakan adalah benarkah sebuah teks dapat diterima sebagai kenyataan? Sedangkan kritik eksternal dimaksudkan untuk memeriksa keaslian dokumen, siapa pembuat, bagaimana bahasa dan bentuknya, serta sumbernya (Kartodirdjo 1997:59). Data yang diperoleh dari surat kabar dan media sosial dalam penelitian ini diperiksa melalui kritik internal dan eksternal sehingga data yang diolah telah melalui penyaringan secara ketat.

Data tersebut selanjutnya diolah dan dianalisis menggunakan langkah kerja yang dirancang Gamson dan Mondigliani. Langkah kerja itu menganalisis data mulai dari diskursus yang dibentuk oleh media massa hingga diskursus yang dibangun oleh masyarakat (Gamson and Modigliani 1989). Pada penelitian ini, diskursus dari media massa diperoleh dari media massa lokal yang beredar di Kota Malang. Data diperoleh dari berita perayaan ulang tahun ke-29 Arema yang spesifik memuat pelarangan konvoi Aremania di website Surya Malang sejumlah 19 judul artikel berita. Surya Malang dipilih sebagai sumber data utama sebab harian ini yang secara konsisten memberitakan perihal pelarangan konvoi perayaan ulang tahun Arema. Data dari harian Surya itu dilengkapi dengan empat judul berita yang dimuat di koran Radar Malang. Meskipun secara kuantitas jumlah berita di Radar Malang tidak sebanyak Surya, namun distribusi koran ini dipandang signifikan untuk menyebarkan diskursus di Kota Malang.Data dari kedua media massa tersebut selanjutnya dibandingkan dengan diskursus yang berkembang di masyarakat di dalam jejaring sosial Twitter yang memperbincangkan tentang perayaan ulang tahun Arema yang ke-29.

\section{KRONOLOGI PERISTIWA}




\section{I IndharWahyuWiraHarjo}

Perebutan pengaruh antara negara, pasar, dan masyarakat sipil dalam kasus

Upaya Polres Malang untuk mengelola pergerakan masa pada saat perayaan ulang tahun ke-29 Arema didasari sejumlah pertimbangan. Antisipasi tersebut berkaitan dengan permasalahan yang kerap muncul ketika terjadi pergerakan Aremania dalam jumlah besar di wilayah Malang Raya. Permasalahan yang sering terjadi pada saat konvoi Aremania diantaranya adalah kemacetan lalu lintas, peningkatan jumlah kecelakaan di jalan raya, hingga perusakan kendaraan bermotor.

Permasalahan kemacetan di jalan raya Kota Malang ini dipicu oleh beberapa faktor penting. Pemicu pertama berkaitan dengan penambahan jumlah kendaraan yang secara masif, setiap tiga bulan terdapat peningkatan jumlah kendaraan sebanyak 6 ribu unit dengan rincian 4 ribu motor dan 2 ribu mobil baru. Pemicu kedua berhubungan dengan jumlah pendatang yang bertambah setiap tahun, terutama mahasiswa yang berjumlah sekitar 60 ribu orang dari 53 Perguruan Tinggi di Kota Malang. Selain itu permasalahan ini juga berhubungan dengan ketiadaan pembangunan jalan baru dan pelebaran jalan yang signifikan turut menjadi faktor penentu terjadinya kemacetan di jalan raya (Radar Malang 2016:29).

Perayaan hari ulang tahun Arema pada tanggal 11 Agustus diprediksi melibatkan ribuan Aremania dari seluruh wilayah Malang Raya. Kehadiran Aremania tersebut tentu saja akan memadati semua ruas jalan dan menyebabkan kemacetan lalu-lintas (Mashita 2016; Satrio 2016). Mobilitas Aremania secara besar-besaran ini acapkali merepotkan pengguna jalan yang tidak terlibat dalam arak-arakan, mereka kerap harus menepi dan berhenti untuk memberikan jalan bagi rombongan Aremania yang sedang melintas.

Selain permasalahan kemacetan jalan, konvoi kendaraan bermotor juga meningkatkan peluang kecelakaan lalu lintas. Hal ini bisa terjadi sebab pawai kendaraan bermotor semacam itu seringkali memunculkan pelanggaran lalu lintas. Pelanggaran tersebut dianggap menjadi pemicu terjadinya kecelakaan lalu lintas. Pelanggaran aturan lalu lintas yang dinilai sebagai pemicu kecelakaan lalu lintas yang terjadi pada saat konvoi antara lain tidak mengenakan helm pengaman untuk pengendara kendaraan beroda dua, menggunakan kendaraan bak terbuka untuk mengangkut orang, dan mengendarai kendaraan bermotor tanpa dilengkapi surat-surat yang lengkap dan sah (Mashita 2016; Ramadhan 2016; Wahyunik 2016d).

Masalah yang tidak kalah krusial berkaitan dengan ancaman perusakan kendaraan bermotor. Pada saaat pawai kendaraan bermotor para Aremania, pengguna 
jalan yang lain tak jarang menjadi sasaran perusakan. Kejadian semacam ini jamak terjadi pada kendaraan bermotor dengan plat nomor dari kota sebelah, Surabaya. Pengemudi kendaraan dengan kode plat berhuruf ' $L$ ' seringkali khawatir melintas di jalan wilayah Malang Raya pada saat arak-arakan Aremania berlangsung. Konon kendaraan dari kota tersebut dianggap sebagai musuh yang perlu dihantam sebab salah satu klub sepakbola asal Surabaya merupakan rival abadi Arema. Meskipun ada pula mobil plat 'L' yang dirusak ternyata bukan milik warga Kota Surabaya, melainkan orang Malang yang membeli mobil di Surabaya (Wahyunik 2016c). Kekerasan semacam ini dapat terjadi atas dasar perbedaaan nilai-nilai yang mengikat pendukung klub sepakbola, lebih lanjut gangguan semacam ini juga juga terjadi berdasar perbedaan sosiodemografi (Zani and Kirchler 1991:5). Dalam konteks ini berarti kekerasan yang terjadi bermula dari perbedaan nilai-nilai yang dianut Aremania dan Bonekmania (pendukung klub sepakbola asal Surabaya) dan perbedaan sosiodemografi antara Kota Malang dan Surabaya. Aremania menganut nilai yang tampak dalam slogan 'Salam Satu Jiwa: Arema', sedangkan Bonekmania mempercayai jargon 'Salam Satu Nyali: Wani'.

Permasalahan yang berpeluang terjadi pada saat terjadi arak-arakan kendaraan bermotor Aremania mendorong Polres Kota Malang untuk melakukan penertiban. Upaya penertiban tersebut dilakukan dengan cara memberlakukan larangan pawai kendaraan bermotor pada hari Kamis, 11 Agustus 2016. Pada hari itu, Aremania tidak diperkenankan melakukan konvoi keliling kota untuk merayakan hari kelahiran klub Arema yang juga dikenal dengan namaSingo Edan. Kebijakan tersebut disampaikan oleh jajaran Kepolisian Kota Malang, Kabupaten Malang dan Kota Batu pada saat sosialisasi kepada perwakilan Aremania pada tanggal 09 Agustus di Aula Polres Malang (Hartik 2016; Wahyunik 2016a; Zuk 2016).

Kebijakan yang dilakukan oleh jajaran Kepolisian Malang Raya ini dapat dipandang sebagai upaya negara untuk mengatur tindakan warganya. Kebijakan yang disepakati oleh tiga resort di wilayah Malang Raya itu dimaksudkan untuk memberikan batasan atas perilaku kolektif yang hendak dilakukan Aremania. Dasar atas pemberlakuan kebijakan tersebut ditekankan pada pertimbangan bahwa tanggal 11 Agustus 2016 bertepatan dengan hari Kamis yang berarti masih ada aktivitas sekolah dan kerja bagi warga Kota Malang (Zuk 2016). 


\section{I IndharWahyuWiraHarjo}

Perebutan pengaruh antara negara, pasar, dan masyarakat sipil dalam kasus

Perbincangan yang melibatkan tiga Kapolres di wilayah Malang Raya, manajemen Arema dan Aremania berlangsung sengit. Pertemuan yang diselenggarakan secara tertutup di Aula Polres Kota Malang tersebut berlangsung sejak pagi hingga siang hari. Pertemuan itu tak kunjung memunculkan konsensus yang disepakati para aktor yang terlibat di dalamnya. Pihak Kepolisian bersikukuh untuk membatasi konvoi yang hendak dilakukan Aremania pada perayaan ulang tahun Singo Edan. Sedangkan kubu manajemen bersama perwakilan Aremania bersikeras melakukan arak-arakan pada hari Kamis 11 Agustus 2016.

Manajemen Arema bersama Aremania berusaha mempertahankan argumen yang memungkinkan terjadinya mobilitas rombongan Aremania keliling Malang Raya. Gagasan yang dipertahankan keduanya berkisar pada pelestarian tradisi perayaan ulang tahun yang selama ini telah dilakukan (Wahyunik 2016a). Tradisi perayaan ulang tahun yang dimaksud adalah perayaan yang dilakukan secara terpusat di sekitar Kantor Arema dan dilanjutkan dengan pawai keliling wilayah Malang Raya. Pawai tersebut dari tahun ke tahun selalu melibatkan ribuan Aremania dari seluruh penjuru Malang Raya.

Konvoi yang melibatkan ribuan Aremania memang bukan menjadi satu-satunya agenda manajemen untuk merayakan ulang tahun Arema kali itu. Sejumlah kegiatan telah dirancang sebagai rentetan perayaan hari jadi klub kebanggaan warga Malang. Kegiatan tersebut telah direncanakan dengan kegiatan-kegiatan pemutaran film dokumenter Arema, pertunjukan kembang api, lomba mewarna, bazar, lomba desain $t$ shirtresmi Arema, tasyakuran, bedah buku, talk show, dan pertunjukan musik. Sejumlah acara tersebut direncanakan berawal dari hari Rabu 10 Agustus hingga 14 Agustus 2016 (Permana 2016; Rekohadi 2016a). Kegiatan yang dipusatkan di sekitar kantor Arema tersebut menjadi daya tarik luar biasa bagi Aremania dari seluruh Malang Raya. Alhasil, kendati konvoi kendaraan secara resmi dilarang, pergerakan para Aremania dari dan menuju pusat perayaan ulang tahun tersebut sudah mirip dengan konvoi itu sendiri.

Kegiatan-kegiatan yang telah dirancang manajemen Arema untuk merayakan hari jadi berorientasi pada partisipasi sebanyak mungkin dari Aremania. Atas dasar gagasan itu, manajemen Arema berupaya keras untuk menolak kebijakan membatasi konvoi yang dilakukan Aremania di hari perayaan ulang tahun yang ke-29. Larangan Polres Kota Malang itu memang tidak berimbas bagi kelangsungan manajemen Arema 
secara langsung. Namun manajemen Arema menilai kebijakan tersebut dapat berdampak negatif bagi kelangsungan acara-acara yang telah disiapkan jauh-jauh hari.

Pernyataan yang disampaikan perihal larangan konvoi sontak ditentang pihak manajemen Arema dan Aremania. Penolakan Aremania atas kebijakan pihak kepolisian dapat dipahami, sebab mereka menilai konvoi merupakan bagian dari tradisi yang perlu dipertahankan. Namun bagaimana dengan ketidaksetujuan manajemen Arema atas regulasi itu? Apakah keputusan itu bersentuhan dengan kebutuhan manajemen Arema?

Konvoi menjadi bentuk perayaan yang diinginkan oleh Aremania, suporter Singo Edan menyebutnya sebagai tradisi. Konvoi sebagai tradisi menyemarakkan hari ulang tahun itu menjadi bagian dari kebahagiaan Aremania (Wahyunik 2016a). Konvoi maka dari itu dilihat sebagai kepingan kebahagiaan Aremania untuk merayakan hari lahir klub sepak bola kebanggaannya. Sehinga pada saat konvoi dilarang oleh pihak kepolisian, Aremania beramai-ramai menolak keputusan itu.

Penolakan Aremania terhadap kebijakan pelarangan konvoi berakhir 'indah'. Polisi memang bersikukuh pada keputusan untuk melarang Aremania melakukan arakarakan kendaraan bermotor di hari Kamis tanggal 11 Agustus. Namun Aremania boleh melakukan konvoi pada hari Minggu 14 Agustus 2016 dengan tajuk 'napak tilas'. Napak tilas ini menjadi angin segar bagi Aremania yang berkeinginan mempertahankan tradisi merayakan ulang tahun Arema dengan jalan mengadakan pawai keliling wilayah Malang Raya.

Napak tilas tidak memperlihatkan kekuatan polisi dalam mengatur tindakan Aremania. Di event ini, pada akhirnya justru pihak kepolisian harus turun tangan untuk melakukan pengawalan pada arak-arakan yang dilakukan Aremania pada tanggal 14 Agustus tersebut. Polisi yang dilibatkan dalam perayaan ini bertugas melakukan pengawalan rombongan Aremania sedari Stadion Gajayana di Kota Malang menuju Stadion Kanjuruhan di Kabupaten Malang dengan panjang rute perjalanan berkisar 23 km (Rekohadi 2016b). Jumlah aparat kepolisian yang ditugaskan mengamankan dan menertibkan acara tersebut tercatat sebanyak 750 personel (Wahyunik 2016b). 
Tabel 1. Kronologi Peristiwa dan Imbasnya

\begin{tabular}{|c|c|c|}
\hline Tanggal & Peristiwa & Imbas \\
\hline 09 Agustus & $\begin{array}{l}\text { Polisi Resort Malang Kota, Kabupaten } \\
\text { Malang dan Kota Batu melakukan } \\
\text { sosialisasi pelarangan konvoi HUT } \\
\text { Arema. }\end{array}$ & $\begin{array}{c}\text { Perwakilan Aremania menolak } \\
\text { kebijakan pelarangan konvoi. }\end{array}$ \\
\hline 10 Agustus & $\begin{array}{l}\text { Pemutaran film refleksi perjalanan } \\
\text { Arema dan pesta kembang api di } \\
\text { Bundaran Tugu Malang mulai pukul } \\
\text { 23.00 WIB. }\end{array}$ & $\begin{array}{l}\text { Terjadi mobilisasi Aremania } \\
\text { menuju Bundaran Tugu dan } \\
\text { penutupan jalan sekitar lokasi } \\
\text { pemutaran film. }\end{array}$ \\
\hline 11 Agustus & $\begin{array}{l}\text { Pembukaan Bazar, Lomba Mewarnai, } \\
\text { Lomba Desain } t \text {-shirt, tasyakuran, bedah } \\
\text { buku, dialog dan konser musik di depan } \\
\text { Kantor Arema Cronus. }\end{array}$ & $\begin{array}{c}\text { Terdapat konsentrasi Aremania di } \\
\text { lokasi kegiatan. }\end{array}$ \\
\hline 12-13 Agustus & $\begin{array}{l}\text { Bazar dan Festival Musik di depan } \\
\text { Kantor Arema Cronus. }\end{array}$ & $\begin{array}{c}\text { Terdapat konsentrasi Aremania di } \\
\text { lokasi kegiatan. }\end{array}$ \\
\hline 14 Agustus & $\begin{array}{l}\text { Napak tilas dari Stasiun Kota Baru menuju } \\
\text { Stadion Kanjuruhan dan kembali menuju } \\
\text { Stasiun Kota Baru, Konser Musik dan } \\
\text { Nonton Barengpertandingan Sriwijaya FC } \\
\text { melawan Arema Cronus di depan Kantor } \\
\text { Arema Cronus. }\end{array}$ & $\begin{array}{c}\text { Terjadi mobilisasi dan konsentrasi } \\
\text { Aremania di sepanjang rute } \\
\text { napak tilas. }\end{array}$ \\
\hline
\end{tabular}

\section{MENDUDUKAN KEPENTINGAN PARA PIHAK}

Kedudukan para pihak yang terlibat dalam pelaksanaan perayaan Hari Ulang Tahun Arema akan ditempatkan berdasarkan karakteristiknya masing-masing. Para aktor yang teridentifikasi berkaitan dengan peristiwa tersebut dapat diklasifikasikan ke dalam tiga kelompok utama, antara lain: Polisi, Manajemen Arema FC dan Aremania. Tiga kelompok tersebut menjadi pihak-pihak yang terlibat dalam peristiwa perayaan hari ulang tahun Arema yang ke-29.

Klasifikasi para pihak yang berkaitan dengan peristiwa perayaan ulang tahun arema dilakuan dengan mempertimbangkan ciri dari masing-masing kelompok. Kelompok polisi merupakan pihak yang bermaksud melakukan pengaturan terhadap kelompok Manajemen Arema dengan kelompok Aremania. Kelompok polisi dalam peristiwa tersebut terdiri dari Polisi Resort MalangKota, Polisi Resort Malang (Kabupatan Malang) dan Polisi Resort Kota Batu. Pihak kepolisian yang terlibat dalam peristiwa ini selanjutnya diwakili oleh Kapolres Malang Kota yang saat itu dijabat oleh AKBP Decky Hendarsono, Kapolres Malang AKBP Agus Yulianto dan Kapolres Batu AKBP Leonardus Simarmata. 
Pada peristiwa ini, pihak kepolisian memiliki tujuan yang berhubungan dengan pihak Manajemen Arema dan Aremania. Pihak kepolisian menyatakan bahwa pada perayaan hari ulang tahun Arema yang melibatkan pengerahan massa di jalan raya sebagai kegiatan terlarang. Argumen utama yang dimunculkan pihak kepolisian berkaitan dengan waktu perayaan yang bertepatan dengan hari Kamis yang berstatus hari aktif, itu berarti kegiatan pelajar di sekolah masih diselenggarakan.

Kebijakan itu dilakukan sebagai stategi preventif untuk mencegah sejumlah permasalahan yang berpotensi terjadi pada saat perayaan ulang tahun Arema diselenggarakan. Kebijakan ini dapat dilihat sebagai upaya negara untuk mengatur perilaku pendukung klub sepakbola. Negara memiliki tentara dan polisi untuk memaksa warga negara (Duke and Crolley 2014:4), sehingga dalam hal ini polisi idealnya memiliki kekuatan untuk memaksa Aremania membatalkan rencana konvoi pada hari ulang tahun Arema. Alih-alih mendapatkan kepatuhan, ternyata regulasi itu justru menghadirkan perlawanan dari pihak manajemen Arema dan ribuan Aremania.

Keputusan bersama Polres Malang Raya itu ditentang para pihak, terutama Manajemen Arema dan Aremania. Pihak suporter Arema mendesak adanya perayaan ulang tahun yang diwujudkan dalam bentuk konvoi di jalan raya. Usulan itu memperoleh dukungan dari Manajemen Arema Cronus yang diwakili oleh Bagian Hubungan Masyarakat saat itu, Sudarmaji. Sudarmaji menyatakan bahwa Aremania memiliki tradisi untuk merayakan hari ulang tahun Arema dengan aktivitas konvoi kendaraan bermotor di jalan raya.

Manajemen memperjuangkan dan memfasilitasi keinginan Aremania untuk melakukan konvoi sebab suporter merupakan aset yang sangat berharga bagi klub sepakbola. Suporter menjadi aset penting sebab mereka memiliki investasi personal dan emosional berjangka panjang pada klub (Giulianotti 2002:33). Penjelasan tersebut menunjukkan bahwa keterikatan personal dan emosional jangka panjang Aremania kepada Arema menjadi kekayaan yang penting dipertahankan. Dengan demikian loyalitas Aremania kepada Arema perlu dipertahankan dan direproduksi oleh manajemen Arema. Sebagai bentuk konkret atas upaya tersebut, manajemen Arema harus berupaya menyokong penolakan terhadap kebijakan larangan konvoi yang menyasar Aremania. 


\section{I IndharWahyuWiraHarjo}

Perebutan pengaruh antara negara, pasar, dan masyarakat sipil dalam kasus

Diperlukan sejumlah argumen kuat dimunculkan untuk mempertahankan gagasan suporter sebagai aset di atas. Gagasan lain yang patut dipertimbangkan ditemukan dari situs jejaring sosial twitter. Twitter dimanfaatkan Aremania untuk meluapkan ketidaksetujuannya atas pelarangan konvoi menyemarakkan ulang tahun ke29 kesebelasan Arema. Salah satu pernyataan dari Aremania berikut ini dapat menjadi penjelasan menarik mengenai upaya manajemen 'memfasilitasi' Aremania untuk melakukan konvoi pada 11 Agustus. Akun twitter @lazir_ongisnade menuliskan keluh kesahnya pada tanggal 10 Agustus 2016. Pernyataan tersebut dituliskan sebagai berikut:

“@AremafcOfficial@we_aremania jangan salahkan kami bila Kanjuruhan sepi aremania... Wong dihari jadi arema kami aremania dilarang konvoi cox".

Pernyataan tersebut menunjukkan ancaman kepada manajemen Arema apabila konvoi pada saat perayaan ulang tahun Singo Edan dilarang. Ancaman itu berhubungan dengan boikot yang hendak dilakukan Aremania pada pertandingan kandang sepakbola Arema di Stadion Kanjuruhan Kabupaten Malang.
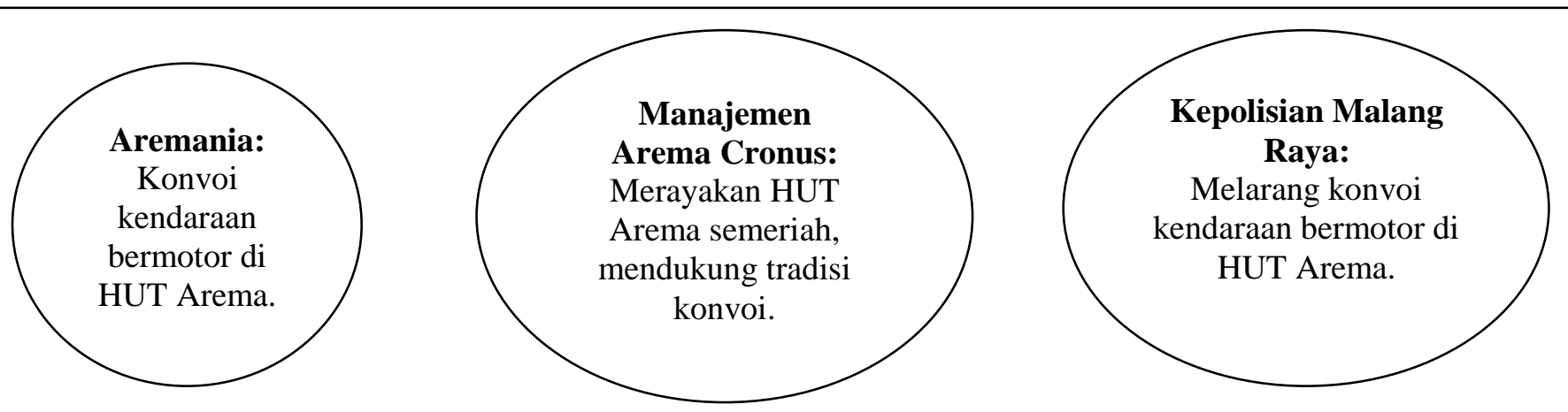

Gambar 1. Perbedaan kepentingan para pihak yang dibingkai media

\section{GESEKAN KEPENTINGAN PARA PIHAK}

Peristiwa pelarangan konvoi perayaan hari ulang tahun Arema ke-29 menunjukkan relasi sosial yang menarik. Keterlibatan polisi, Manajemen Arema dan Aremania dalam sengkarut implementasi kebijakan ini menunjukkan praktik kekuasaan melibatkan sejumlah aktor yang berkepentingan. Pertautan praktik kuasa yang dilakukan para aktor dalam peristiwa ini menunjukkan upaya untuk saling mempengaruhi pihak-pihak memiliki kepentingan dalam perayaan hari ulang tahun Arema. 
Kebijakan yang dirancang Polres Kota Malang, Kabupaten Malang dan Kota Batu merepresentasikan kekuatan dari institusi negara dalam mengatur perilaku warga negara. Bentuk konkret dari pola semacam itu dapat diamati dari pembingkaian media pada saat mempublikasikan pernyataan berikut:

"Kalau (Aremania, pen) tidak mematuhi ketertiban berlalu lintas, tentunya kami tindak tegas," ujar Kasatlantas Polres Malang Kota, AKP David Trio Prasojo.(Fahlevi 2016)

Pernyataan itu menunjukkan kepentingan pihak kepolisian untuk memanipulasi perilaku Aremania saat merayakan hari jadi klub sepak bola Arema. Polisi menginginkan dan merancang strategi agar Aremania tidak melakukan konvoi keliling Malang Raya pada hari itu. Kekuasaan institusi negara pada konteks ini didorong untuk bekerja dalam pola yang bersifat koersif.

Cara kerja kekuasaan ternyata tidak sekedar berorientasi pada pemaksaan. Kekuasaan bukan sekadar upaya memaksa orang lain agar melakukan sesuatu yang sebenarnya tidak ingin dilakukannya. Namun kekuasaan juga beroperasi dengan jalan mempengaruhi, membentuk atau menentukan keinginan seseorang (Lukes 2005:27). Pada konteks ini, pihak kepolisian berupaya untuk menjalankan kekuasaan yang dimilikinya dengan cara mempengaruhi Aremania agar tidak melakukan arak-arakan pada tanggal 11 Agustus. Polisi berusaha untuk membentuk kebutuhan Aremania yang melakukan perayaan ulang tahun klub sepak bolaArema dengan menekankan pada urgensi menciptakan keamanan dan mempertahankan ketertiban umum di wilayah Malang Raya.

Strategi polisi untuk mencapai tujuannya untuk mengatur konvoi Aremania diwujudkan dalam kebijakan bersama polisi di Malang Raya. Polres Kota Malang, Kabupaten Malang dan Kota Batu memiliki kesepakatan untuk melarang Aremania melakukan mobilitas massal pada tanggal 11 Agustus. Pengambilan keputusan tersebut melibatkan manajemen Arema dan perwakilan Aremania yang dilakukan pada tanggal 09 Agustus di Aula Polres Kota Malang. Pada tahapan ini, kekuasaan dioperasikan dalam proses pengambilan keputusan. Praktik kuasa yang difokuskan pada perilaku dan proses pengambilan keputusan semacam ini dapat dikategorikan sebagai cara pandang kekuasaan satu dimensi, yaitu praktik kuasa yang secara langsung digunakan untuk mempengaruhi perilaku orang lain(Lukes 2005:29). 


\section{I IndharWahyuWiraHarjo}

Perebutan pengaruh antara negara, pasar, dan masyarakat sipil dalam kasus

Selain praktik kuasa yang dijalankan polisi, peristiwa ini juga memperlihatkan strategi kekuasaan yang dilakukan oleh Manajemen Arema. Berbeda dengan pihak kepolisian yang lebih menekenakan pada pengaturan perilaku melalui pengambilan keputusan, praktik kuasa yang dijalankan Manajemen Arema beroperasi pada proses yang bersifatnon decison-making. Manajemen Arema terlibat dalam perumusan kebijakan perihal perayaan dirgahayu Singo Edan dengan pihak kepolisian, namun keterlibatan itu tidak dapat mengatur atau mempengaruhi pengambilan keputusan yang dilakukan polisi.Manajemen Arema turut membentuk perilaku Aremania pada pesta perayaan ulang tahun yang ke-29. Pembentukan perilaku itu dapat diamati dalam pernyataan perwakilan Manajemen Arema yang dikutip dalam berita berikut ini:

"Manajemen bersama kepolisian menghimbau agar konvoi sebisa mungkin tidak digelar karena hari Kamis (11/8/2016) adalah hari kerja kantor dan hari sekolah. Polisi sepakat konvoi bisa digelar hari Minggu dalam kegiatan napak tilas," papar Sudarmaji. (Rekohadi 2016b)

Pernyataan di atas memperlihatkan bahwa Manajemen Arema berada dalam koridor menjalankan kebijakan yang diterapkan kepolisian Malang Raya. Keputusan untuk mengikuti kebijakan yang dibuat negara memperlihatkan kedudukanManajemen Arema dalam peristiwa ini.

Posisi Manajemen Arema pada kenyataanya bukan merupakan aktor yang bersifat pasif. Manajemen Arema juga mempengaruhi perilaku pihak lain agar kepentingannya tetap terjaga. Pembentukan perilaku sebagai bentuk praktik kuasa itu dijalankan dengan 'menentukan' kebutuhan Aremania. Manajemen Arema berusaha untuk membentuk dan menentukan kebutuhan dengan cara menyelenggarakan kegiatankegiatan yang bersifat pencapaian prestasi dan hiburan. Manajemen Arema telah menyiapkan kegiatan yang berorientasi pada pencapaian prestasi seperti lomba mewarnai dan lomba mendesain t-shirt official Arema. Selain kegiatan yang berorientasi pada prestasi, kebutuhan Aremania pada saat merayakan ulang tahun klub andalannya dalam bentuk acara hiburan semacam pertunjukan musik, pemutaran film dokumenter, dan nonton bareng pertandingan Arema. Upaya menentukan kebutuhan Aremania dengan logika semacam ini menunjukkan praktik kuasa yang bersifat nondecision-making. Sehingga pola praktik kuasa yang dilangsungkan manajemen Arema ini dapat dikategorikan sebagai cara pandang kekuasaan dua dimensi (Lukes 2005:29). Cara pandang kekuasaan dua dimensi ini mencoba memahami praktik kuasa 
dalam koridor decision-making sekaligus nondecision-making. Hal ini berarti bahwa Manajemen Arema mengikuti kebijakan yang diambil kepolisian namun juga melakukan upaya mempengaruhi perilaku pihak lain, tanpa membuat kebijakan baru atau melanggar kebijakan yang telah ditentukan.

Kebijakan pihak kepolisian Malang Raya melarang konvoi Aremania ini menunjukkan jalinan yang menarik saat diulas dalam koridor relasi kuasa. Polisi bermaksud menjalankan praktik kuasa pada Aremania dengan menyuntikkan kepentingannya ke dalam keputusan yang melarang arak-arakan. Polisi mendesak Aremania menghindari konvoi seperti yang diinginkan dengan harapan agar ketertiban dan keamanan lalu lintas di Kota Malang dapat dijaga. Untuk membuat dan menjalankan kebijakan tersebut, polisi melibatkan manajemen Arema dan perwakilan Aremania. Akan tetapi pelarangan itu pada akhirnya dinegosiasikan sehingga memunculkan kebijakan baru yang dikenal dengan sebutan 'napak tilas'.

Napak tilas sebagai sebuah keputusan dipengaruhi oleh kepentingan polisi, manajemen Arema dan tentu saja Aremania. Napak tilas tidak mengakomodasi kepentingan polisi untuk meniadakan konvoi untuk merayakan ulang tahun Arema. Napak tilas ini sedianya bukan pula menjadi agenda dalam kegiatan pesta hari jadi yang dirancang Manajemen Arema. Napak tilas ini juga tak menjadi pemenuhan keinginan Aremania untuk turun ke jalan pada tanggal 11 Agustus. Napak tilas ini memperlihatkan dimensi lain dari jalannya kekuasaan dalam bentuk negosiasi antaraktor pada proses decision-making.

Aremania dalam berita-berita yang dipublikasi di media-media massa memperlihatkan ketidaksetujuan dengan kebijakan larangan konvoi. Pernyataanpernyataan yang dikutip dalam berita berikut ini memperlihatkan pembingkaian yang dilakukan terkait dengan tuntutan dari Aremania:

"Kami ingin konvoi. Aremania keluar beriringan dari gang rumah itu sudah konvoi, tidak setuju kalau dilarang," tegas Udin Muharto.

"Kami berkomitmen akan menjaga ketertiban dan keamaanan selama konvoi," ujar iin.(Wahyunik 2016a)

Pernyataan yang ditampilkan dalam berita tersebut memperlihatkan kepentingan yang disuarakan oleh Aremania. Aremania memiliki kepentingan dan keinginan untuk melakukan konvoi dalam rangka merayakan hari ulang tahun Arema. Dalam 
pembingkaian di atas, diperlihatkan pula usaha yang dilakukan Aremania untuk meyakinkan pihak kepolisisan dan Manajemen Arema bahwa mereka berkomitmen untuk melakukan konvoi secara aman dan tertib.

Negosiasi antaraktor yang terlibat dalam peristiwa ini memperlihatkan relasi yang menarik. Polisi, Manajemen Arema dan Aremania memiliki tujuan masing-masing yang berbeda satu sama lain. Perbedaan tujuan tersebut mendorong para pihak untuk saling mempengaruhi, mengarahkan, dan membentuk kepentingan pihak lain agar tujuannya tercapai. Ketiga pihak yang terlibat dalam tarik-ulur kebijakan ini mencoba mempengaruhi pihak-pihak yang lain dengan berbagai cara.

Polisi yang memiliki tujuan melarang konvoi kendaran bermotor berusaha kuat untuk mempengaruhi manajemen Arema dan Aremania. Ketika mengorientasikan tujuannya untuk membentuk perilaku Aremania melalui kebijakan, polisi memperlihatkan praktik yang berada dalam koridor decision-making. Praktik kuasa dalam dimensi ini bermaksud untuk mengarahkan perilaku orang lain agar sesuai dengan tujuannya sendiri, kendati orang tersebut sebenarnya tidak mau melakukan hal itu. Sehingga pada tahapan ini polisi terlihat sedang mengatur perilaku Manajemen Arema dan juga Aremania agar sesuai dengan tujuan yang diinginkan polisi. Kebijakan pihak kepolisian Malang Raya tidak serta-merta dipatuhi oleh keduanya. Alih-alih mematuhi arahan polisi, manajemen Arema dan Aremania justru mengkritisi kebijakan tersebut. Manajemen Arema dan Aremania melakukan peninjauan pada kebijakan itu sehingga pada akhirnya polisi melakukan perubahan atas kebijakan itu.

Peristiwa ini menunjukkan bahwa kekuasaan selain memuat dimensi decisionmaking dan nondecision-making juga mengandung unsur kontrol terhadap agenda politik. Inilah yang dipahami sebagai cara pandang kekuasaan tiga dimensi (Lukes 2005:29). Manajemen Arema dan Aremania melakukan pengawasan terhadap kebijakan yang diberlakukan sehingga berpeluang untuk menegosiasi kebijakan yang akan diimplementasikan. Alhasil, acara napak tilas muncul sebagai bentuk decision-making dan nondecision-making yang lahir dari control over political agenda.

\section{KESIMPULAN}

Pemberitaan mengenai 'napak tilas' yang dilakukan Aremania menunjukkan bahwa strategi yang dijalankan negara untuk mengatur perilaku masyarakat sipil berakhir percuma. Kekuasaan yang dimiliki institusi negara dalam 
mengimplementasikan kebijakan terbukti tidak mampu mengarahkan perilaku masyarakat. Alih-alih memberikan koridor dalam perilaku, tujuan institusi untuk mengatur perilaku yang diwujudkan dalam kebijakan tersebut justru ditentang oleh korporasi dan organisasi masyarakat sipil. Penentangan terhadap kebijakan itu memperlihatkan kontrol atas regulasi yang ditetapkan negara. Kontrol itu berhasil dilakukan sampai pada tingkat merubah kebijakan yang telah diberlakukan. Di sisi lain, peristiwa napak tilas ini mengilustrasikan pula keredupan kekuatan masyarakat sipil dalam mengkontrol kebijakan negara. Pada konteks ini masyarakat sipil harus bekerjasama dengan korporasi untuk mengubah regulasi negara. Korporasi seolah-olah menempatkan diri sebagai mediator dalam peristiwa ini. Namun secara faktual, korporasi memfasilitasi masyarakat sipil sebab memiliki kepentingan untuk mempertahankan loyalitas masyarakat sipil terhadapnya. Sehingga peristiwa ini menggambarkan silang-sengkarut kepentingan dan kekuasaan para aktor yang terlibat di dalamnya. Berdasarkan kondisi semacam ini, relasi antara negara, masyarakat sipil dan korporasi dapat diorientasikan kepada model hubungan yang bersifat saling menguntungkan. Relasi antara tiga elemen penting itu pada akhirnya tidak mesti berada dalam koridor yang bersifat dominatif maupun eksploitatif.

\section{DAFTAR PUSTAKA}

Colombijn, Freek. 2000. “The Politics of Indonesian Football.” Archipel 59:171-200.

Damsar. 2010. Pengantar Sosiologi Politik. Jakarta: Kencana Prenadamedia Group.

Duke, Vic and Liz Crolley. 2014. Football, Nationality and the State. New York: Routledge.

Eriyanto. 2002. Analisis Framing: Konstruksi, Ideologi Dan Politik Media. Yogyakarta: LKiS.

Fadiyah, Dina. 2014. “Analisis Framing Pemberitaan Ahok vs Lulung Dalam Konflik Penertiban PKL Di Pasar Tanah Abang Jakarta Pusat Dalam Media Online Detik.Com." Al-Azhar Indonesia Seri Pranata Sosial 2(3):169-76.

Fahlevi, Fahdi. 2016. "Rayakan Ulang Tahun Arema, Aremania Malah Dirazia Polisi." Tribunnews.Com. Retrieved (http://www.tribunnews.com/superskor/2016/08/11/rayakan-ulang-tahun-aremaaremania-malah-dirazia-polisi.).

Foer, Franklin. 2006. Memahami Dunia Lewat Sepak Bola. Tangerang: Marjin Kiri. 
Gamson, William and Andre Modigliani. 1989. "Media Discourse and Public Opinion on Nuclear Power : A Constructionist Approach." American Journal of Sociology 95(1):1-37.

Giulianotti, R. 2002. "Supporters, Followers, Fans, and Flaneurs: A Taxonomy of Spectator Identities in Football." Journal of Sport \& Social Issues 26(1):25-46.

Giulianotti, Richard. 2006. Sepak Bola: Pesona Sihir Permainan Global. Yogyakarta: Aperion Philotes.

Giulianotti, Richard and Roland Robertson. 2004. "The Globalization of Football: A Study in the Glocalization of the 'Serious Life."' British Journal of Sociology 55(4):545-68.

Hartik, Andi. 2016. "Tidak Ada Konvoi Aremania Pada Puncak HUT Ke-29 Arema Kompas.Com.” Kompas. Retrieved October 17, 2016 (http://bola.kompas.com/read/2016/08/10/07180088/Tidak.Ada.Konvoi.Aremania. pada.Puncak.HUT.Ke-29.Arema).

Hasyim, Nanang Mizwar. 2016. "Konstruksi Citra Maskulinitas Calon Presiden (Study Analisis Framing Model Gamson Dan Modigliani Pada Pemberitaan Koran Harian Kompas Dan Jawa Pos Edisi Juni 2014).” Profetik: Jurnal Komunikasi 10(1).

Kartodirdjo, Sartono. 1997. "Metode Penggunaan Bahan Dokumen." in Metode-Metode Penelitian Masyarakat, edited by Koentjaraningrat. Jakarta: Gramedia Pustaka Utama.

Llopis Goig, Ramón. 2008. "Identity, Nation-state and Football in Spain. the Evolution of Nationalist Feelings in Spanish Football.” Soccer \& Society 9(1):56-63.

Lubis, Akhyar Yusuf. 2018. "Paradigma Konstruktivisme Dan Metode Penelitian Pada Ilmu Pengetahuan Sosial Kontemporer." in Metodologi Penelitian Kualitatif: Berbagi Pengalaman dari Lapangan, edited by S. Kholifah and I. W. Suyadnya. Depok: Rajawali Press.

Lukes, Steven. 2005. Power: A Radical View. New York: Palgrave Macmillan.

Mashita, Nani (ed). 2016. “Awas...Aremania Konvoi, Malang Raya Macet LensaIndonesia.Com.” Lensa Indonesia. Retrieved October 17, 2016 (http://www.lensaindonesia.com/2016/04/17/awas-aremania-konvoi-malang-rayamacet.html).

Morrow, Stephen. 2016. "Football, Economic, and Finance." in Routledge Handbook of Football Studies, edited by J. Hughson, K. Moore, R. Spaaij, and J. Maguire. Routledge.

Nugroho, Heru. 2009. "Demokrasi Protektif, Kesejahteraan Sosial Dan Kebijakan Pendidikan Yang Memihak Rakyat." in Negara Minus Nurani: Esai-Esai Kritis 
Jurnalsosiologi $N$ us antara

Vol.5, No.1, Tahun 2019163

Kebijakan Publik, edited by A. F. T. Indratno. Jakarta: Penerbit Buku Kompas.

Permana, Rizky Wahyu. 2016. "Malang - Merdeka.Com | Ini Rangkaian Acara

Peringatan Ulang Tahun Arema Ke-29." Malang Merdeka. Retrieved October 17, 2016 (http://malang.merdeka.com/aremania/ini-rangkaian-acara-peringatan-ulangtahun-arema-ke-29-1608105.html).

Radar Malang. 2016. “Macet Ancam Kesehatan Warga.” Radar Malang, 29.

Ramadhan, Lucky Aditya. 2016. "Banyak Pelanggar, Konvoi Aremania Ditertibkan Polisi - Beritajatim News.” Berita Jatim. Retrieved

(http://beritajatim.com/olahraga/264516/banyak_pelanggar,_konvoi_aremania_dite rtibkan_polisi.html).

Rekohadi, Dyan. 2016a. "HUT Arema, Napak Tilas Akan Digelar Minggu 14 Agustus, Ini Rutenya ... - Surya Malang.” Surya Malang. Retrieved October 17, 2016 (http://suryamalang.tribunnews.com/2016/08/09/hut-arema-napak-tilas-akandigelar-minggu-14-agustus-ini-rutenya).

Rekohadi, Dyan. 2016b. "Ulang Tahun, Arema Gelar Konvoi Napak Tilas Gajayana Kanjuruhan - Halaman 2 - Surya.” Surya Malang. Retrieved October 17, 2016 (http://surabaya.tribunnews.com/2016/08/09/ulang-tahun-arema-gelar-konvoinapak-tilas-gajayana-kanjuruhan?page $=2$ ).

Satrio, Ferry Agusta. 2016. "Arema: Jalanan Macet Konvoi Aremania, Relawan Turun Membantu | Malang TIMES.” Malang Times. Retrieved October 17, 2016 (http://www.malangtimes.com/baca/11938/20160417/160832/jalanan-macetkonvoi-aremania-relawan-turun-membantu/).

Syarifuddin. 2016. "Representasi Ideologi Media Di Balik Wacana Calon Gubernur." Jurnal Studi Komunikasi Dan Media 20(1):1-20.

Wahyunik, Sri. 2016a. "Aremania Ingin Konvoi Saat Rayakan HUT Arema, Tapi Polisi ... - Surya Malang." Surya Malang. Retrieved October 17, 2016

(http://suryamalang.tribunnews.com/2016/08/09/aremania-ingin-konvoi-saatrayakan-hut-arema-tapi-polisi).

Wahyunik, Sri. 2016b. "Ini Jumlah Polisi Yang Jaga Di Perayaan HUT Arema Ke-29 Surya Malang.” Surya Malang. Retrieved October 17, 2016 (http://suryamalang.tribunnews.com/2016/08/10/ini-jumlah-polisi-yang-jaga-diperayaan-hut-arema-ke-29).

Wahyunik, Sri. 2016c. "Polisi Tangkap Dua Suporter Perusak Mobil Di Kota Malang Surya." Surya. Retrieved October 17, 2016

(http://surabaya.tribunnews.com/2016/04/05/polisi-tangkap-dua-suporter-perusakmobil-di-kota-malang).

Wahyunik, Sri. 2016d. "Polisi Tidak Beri Kelonggaran Aremania Konvoi Dan Tilang 
Pelanggar - Surya Malang.” Surya Malang. Retrieved October 17, 2016 (http://suryamalang.tribunnews.com/2016/04/06/polisi-tidak-beri-kelonggaranaremania-konvoi-dan-tilang-pelanggar).

Welki, a. M. and T. J. Zlatoper. 1994. "US Professional Football: The Demand for Game-Day Attendance in 1991." Managerial and Decision Economics 15(5):48995.

Wibowo, Andry. 2017. "Crowds Management in Indonesian Football Event Case Study: Policing Management." Econosains: Jurnal Online Ekonomi Dan Pendidikan 15(2):249-72.

Zani, Bruna and Erich Kirchler. 1991. "When Violence Overshadows the Spirit of Sporting Competition: Italian Football Fans and Their Clubs." Journal of Community and Applied Social Psychology 1(July 1990):5-21.

Zuk. 2016. "Ultah Arema, Polisi Larang Konvoi-Page2 | Radarmalang.Jawapos.Com." Radar Malang. Retrieved October 17, 2016

(http://radarmalang.jawapos.com/read/2016/08/11/2217/-ultah-arema-polisi-larangkonvoi/2). 